\title{
Studies on Thermostability of Newcastle Disease Viruses (Local Isolates) for Preparation of Vaccine
}

\author{
L. Sharma*, U. Biswas, C. Guha, A. Chatterjee, P.S. Jana and R. Pandey \\ Department of Veterinary Epidemiology \& Preventive Medicine, West Bengal University of \\ Animal and Fishery Sciences 37, K. B. Sarani, Kolkata-700037, India \\ *Corresponding author
}

\section{A B S T R A C T}

\begin{tabular}{|l|}
\hline Ke y w or d s \\
Haemagglutination, \\
EID $_{50}$, Thermostability \\
and Newcastle Disease \\
Virus
\end{tabular}

\section{Keywords}

Haemagglutination, EID 50 , Thermostability Virus

\section{Introduction}

Newcastle Disease (ND) is a major constraint to village poultry production throughout developing countries, frequently causing mortality rates of $75 \%$ to $100 \%$ in unvaccinated flocks (Spradbrow, 1992).

Vaccination has been reported as the only safeguard against endemic ND (Usman, 2002). Inactivated vaccines give very good immunity without vaccinal reactions and have been widely used, but are relatively expensive and require considerable attention to training when used by non-veterinary personnel. Live vaccines are easy to apply and relatively inexpensive, and give moderately good immunity. Vaccinal reactions to them vary according to the vaccine strain. Among the live vaccines, the heat resistant vaccines require less stringent transport requirements in the field, and they have also been widely used in villages.

The selection of a ND vaccine for use in rural chicken depends on the local conditions in each country. Selection criteria include - ease of use, cost, thermo stability, immunogenicity, availability and transportability.

In circumstances where the cold chain is weak or absent, the only reliable option will be the 
use of thermo stable ND vaccines; i.e. the live vaccines $\mathrm{NDV}_{4}-\mathrm{HR}$ (Ideris et al., 1987) and $\mathrm{I}_{2}$ (Bensink and Spradbrow, 1999), or inactivated vaccines such as ITANEW and Newcavac. The ACIAR sponsored project for vaccination against ND by using Australian V4 and I2 strains (ND asymptomatic pathotypes) in thirty countries in SEA, Africa and Austria (Spradbrow et al., 1995).

The main objective of the present study is to test the thermo stability in different temperatures of the isolated ND viruses.

\section{Materials and Methods}

Source of the virus for the vaccine production

Viruses used in this study for thermo stability testing were isolated, characterised and provided by the Department of Veterinary Epidemiology and Preventive Medicine, Faculty of Veterinary and Animal Sciences, West Bengal University of Animal and Fishery Sciences, Kolkata-37.

\section{Embryonated Specific Pathogen Free (SPF) fowl eggs}

Embryonated SPF fowl eggs were procured from Venky's (India) Ltd., SPF Eggs Division, Pune for propagation of virus as recommended by OIE, 2009.

\section{Spot/slide agglutination test}

One drop of allantoic fluid, collected during harvesting of virus, was dropped on a grease free glass slide. Freshly prepared $0.5 \%$ chick RBC suspension was added to the allantoic fluid in $1: 1$ ratio $(50 \% \mathrm{v} / \mathrm{v})$. Both the suspensions were mixed thoroughly by rotating the slide gently. The slide was examined by diffused light to see any haemagglutination.
Standard plate Haemagglutination test (HA) as per OIE (2009)

Determination of Embryo Infective Dose fifty (EID50) of the virus as per Reed and Muench (1938) and FAO (2002)

The HA titre was estimated as per OIE (2009) and the Embryo Infective Dose fifty $\left(\mathrm{EID}_{50}\right)$ was determined as per the FAO (2002) and the result was calculated as per Reed and Muench (1938).

\section{Thermo stability testing of the virus isolates}

In the first cycle, vials containing virus were placed in B.O.D incubator at $25^{\circ} \mathrm{C}$ for 36 days. The HA titre and EID $_{50}$ was performed at every 6 days interval. At the end of the first cycle, the virus was passaged in embryonated SPF eggs. In the second cycle, the virus was kept at $37^{\circ} \mathrm{C}$ for 29 days and HA titre and EID $_{50}$ was checked at every 6 days interval. After the end of the second cycle the virus again inoculated in embryonated SPF eggs.

In the third cycle, the virus was exposed to $40^{\circ} \mathrm{C}$ for 30 days and the HA titre and $\mathrm{EID}_{50}$ was performed at every 6 days interval. At the end of the first cycle the virus was passaged in embryonated SPF eggs. In the fourth cycle, the virus was exposed to $43^{0} \mathrm{C}$ for 30 days. The HA titre and $\mathrm{EID}_{50}$ was performed at every 6 days interval. At the end of the cycle the virus was passaged in embryonated SPF eggs and HA activity was checked and virus was stored at $-70^{\circ} \mathrm{c}$ for further use.

\section{Results and Discussion}

All the 5 isolates i.e. L1, L2, L3, L4 and L5 of lentogenic pathotypes of NDV tolerated $25^{\circ} \mathrm{C}$ and $37^{\circ} \mathrm{C}$ temperature for 36 days and 30 days respectively (Table 1 and 2). The L4 isolate tolerated the $40^{\circ} \mathrm{C}$ temperature for 18 days but the $\mathrm{L}_{5}$ isolate showed the HA titre up to the 
end of 30 days cycle. On the other hand, the EID50 of all the five isolates detected up to the end of the cycle. The $\mathrm{L}_{5}$ isolate tolerated the $43^{\circ} \mathrm{C}$ temperature for 12 days (showed HA titre) and EID50 was detected in 30 days heat exposure which means that the $\mathrm{L}_{5}$ isolate showed the longest viability after exposure to the highest temperature and partially fulfilled the objectives and recommendations of the Commission of the European Communities (1993) and OIE (2004) (ICPI of <0.4 if no fewer than $10^{7} \mathrm{EID}_{50}$ or $<0.5$ if no fewer than $10^{8} \mathrm{EID}_{50}$ ) for using as seed virus for preparation of vaccine at room temperature. Here, the lentogenic strain $\mathrm{L}_{5}$ (local isolate) showed the longest viability (showed HA titre up to 12 days and $\mathrm{EID}_{50}$ up to 30 days) exposed to highest temperature $\left(43^{\circ} \mathrm{C}\right)$ having the MDT 98 hours 40 minutes, ICPI 0.06 and IVPI 0.00 along with EID $_{50}$ above $10^{7}$ (Biswas, 2006). Therefore, the $\mathrm{L}_{5}$ isolate has been considered as seed virus after attenuation for preparation of vaccine.

Similar observations were expressed by Chakraborty (2013) and Bhagat (2014) at different temperatures.

Nassien and Adene (2002) reported that Hitchner- $B_{1}$ strain, $\mathrm{K}$ strain completely lost the titre at 72 hours and 95 hours respectively following thermal exposure at $36^{\circ} \mathrm{C}$ temperature. Therefore, from the result it was concluded that all the isolates withstood $37^{\circ} \mathrm{C}$ for long time (30 days) without losing their HA titre (Table 2).

Table.1 Showing HA titre and $\mathrm{EID}_{50}$ of the viruses exposed at $25^{\circ} \mathrm{C}$ for 36 days in the first thermal cycle

\begin{tabular}{|c|c|c|c|c|c|c|c|c|c|c|c|}
\hline \multirow{2}{*}{$\begin{array}{l}\text { Sl. } \\
\text { no. }\end{array}$} & \multirow{2}{*}{$\begin{array}{l}\text { Period of thermal } \\
\text { exposure (in days) }\end{array}$} & \multicolumn{5}{|c|}{ HA titre } & \multicolumn{5}{|c|}{ EID $_{50}$} \\
\hline & & $L_{1}$ & $L_{2}$ & $L_{3}$ & $L_{4}$ & $L_{5}$ & $L_{1}$ & $L_{2}$ & $L_{3}$ & $L_{4}$ & $L_{5}$ \\
\hline 1. & $\begin{array}{c}\text { (before thermal } \\
\text { exposure) }\end{array}$ & $2^{9}$ & $2^{10}$ & $2^{10}$ & $2^{10}$ & $2^{9}$ & $10^{8.67}$ & $10^{9.54}$ & $10^{9.55}$ & $10^{10.32}$ & $10^{9}$ \\
\hline 2. & 6 & $2^{9}$ & $2^{8}$ & $2^{10}$ & $2^{10}$ & $2^{8}$ & $10^{9.25}$ & $10^{8.83}$ & $10^{10.10}$ & $10^{9.55}$ & $10^{9.25}$ \\
\hline 3. & 12 & $2^{9}$ & $2^{8}$ & $2^{10}$ & $2^{9}$ & $2^{8}$ & $10^{9.16}$ & $10^{9.61}$ & $10^{10.33}$ & $10^{9.24}$ & $10^{9.29}$ \\
\hline 4. & 18 & $2^{9}$ & $2^{8}$ & $2^{9}$ & $2^{8}$ & $2^{8}$ & $10^{9.24}$ & $10^{9.42}$ & $10^{9.42}$ & $10^{8.42}$ & $10^{8.75}$ \\
\hline 5. & 24 & $2^{8}$ & $2^{8}$ & $2^{7}$ & $2^{7}$ & $2^{8}$ & $10^{9.79}$ & $10^{8.66}$ & $10^{10.16}$ & $10^{9.5}$ & $10^{8.75}$ \\
\hline 6. & 30 & $2^{8}$ & $2^{7}$ & $2^{7}$ & $2^{7}$ & $2^{8}$ & $10^{8.5}$ & $10^{9.33}$ & $10^{10.33}$ & $10^{8.77}$ & $10^{8.50}$ \\
\hline 7. & 36 & $2^{7}$ & $2^{7}$ & $2^{6}$ & $2^{5}$ & $2^{8}$ & $10^{8.45}$ & $10^{7.65}$ & $10^{9.25}$ & $10^{7.42}$ & $10^{8.50}$ \\
\hline
\end{tabular}

Table.2 The HA titre and $\mathrm{EID}_{50}$ of the viruses exposed at $37^{\circ} \mathrm{C}$ for 30 days in the second thermal cycle

\begin{tabular}{|c|c|c|c|c|c|c|c|c|c|c|c|}
\hline \multirow{2}{*}{$\begin{array}{l}\text { SI. } \\
\text { no. }\end{array}$} & \multirow{2}{*}{$\begin{array}{l}\text { Period of thermal } \\
\text { exposure (in days) }\end{array}$} & \multicolumn{5}{|c|}{ HA titre } & \multicolumn{5}{|c|}{ EID $_{50}$} \\
\hline & & $L_{1}$ & $L_{2}$ & $L_{3}$ & $L_{4}$ & $L_{5}$ & $L_{1}$ & $L_{2}$ & $L_{3}$ & $L_{4}$ & $L_{5}$ \\
\hline 1. & $\begin{array}{l}\text { O(before thermal } \\
\text { exposure) }\end{array}$ & $2^{10}$ & $2^{9}$ & $2^{10}$ & $2^{10}$ & $2^{9}$ & $10^{9.54}$ & $10^{8.83}$ & $10^{10.5}$ & $10^{10.76}$ & $10^{10.16}$ \\
\hline 2. & 6 & $2^{8}$ & $2^{9}$ & $2^{9}$ & $2^{9}$ & $2^{8}$ & $10^{8.66}$ & $10^{9.16 .}$ & $10^{10.25}$ & $10^{8.78}$ & $10^{9}$ \\
\hline 3. & 12 & $2^{7}$ & $2^{8}$ & $2^{7}$ & $2^{8}$ & $2^{8}$ & $10^{8.61}$ & $10^{9.7}$ & $10^{10}$ & $10^{9.56}$ & $10^{8.64}$ \\
\hline 4. & 18 & $2^{6}$ & $2^{8}$ & $2^{6}$ & $2^{6}$ & $2^{7}$ & $10^{9.43}$ & $10^{9.5}$ & $10^{9.62}$ & $10^{10}$ & $10^{8.67}$ \\
\hline 5. & 24 & $2^{6}$ & $2^{7}$ & $2^{6}$ & $2^{6}$ & $2^{7}$ & $10^{9.16}$ & $10^{9.33}$ & $10^{10}$ & $10^{9.24}$ & $10^{8.53}$ \\
\hline 6. & 30 & $2^{5}$ & $2^{6}$ & $2^{5}$ & $2^{5}$ & $2^{7}$ & $10^{9.24}$ & $10^{8.87}$ & $10^{9.39}$ & $10^{9.25}$ & $10^{8.50}$ \\
\hline
\end{tabular}


Table.3 HA titre and $\mathrm{EID}_{50}$ of the viruses exposed at $40^{\circ} \mathrm{C}$ for 30 days in the third thermal cycle

\begin{tabular}{|c|c|c|c|c|c|c|c|c|c|c|c|}
\hline \multirow{2}{*}{$\begin{array}{l}\text { Sl. } \\
\text { no. }\end{array}$} & \multirow{2}{*}{$\begin{array}{l}\text { Period of thermal } \\
\text { exposure (in days) }\end{array}$} & \multicolumn{5}{|c|}{ HA titre } & \multicolumn{5}{|c|}{$\mathrm{EID}_{50}$} \\
\hline & & $L_{1}$ & $L_{2}$ & $L_{3}$ & $L_{4}$ & $L_{5}$ & $L_{1}$ & $L_{2}$ & $L_{3}$ & $L_{4}$ & $L_{5}$ \\
\hline 1. & $\begin{array}{c}0 \text { (before thermal } \\
\text { exposure) }\end{array}$ & $2^{9}$ & $2^{9}$ & $2^{9}$ & $2^{9}$ & $2^{9}$ & $10^{9.54}$ & $10^{8.83}$ & $10^{10.5}$ & $10^{10.76}$ & $10^{10.20}$ \\
\hline 2. & 6 & $2^{8}$ & $2^{6}$ & $2^{7}$ & $2^{5}$ & $2^{7}$ & $10^{8.66}$ & $10^{9.16}$ & $10^{10.25}$ & $10^{8.78}$ & $10^{9.58}$ \\
\hline 3. & 12 & $2^{6}$ & $2^{4}$ & $2^{5}$ & $2^{3}$ & $2^{7}$ & $10^{8.61}$ & $10^{9.7}$ & $10^{10}$ & $10^{9.56}$ & $10^{10}$ \\
\hline 4. & 18 & $2^{3}$ & $2^{1}$ & $2^{1}$ & Nil & $2^{7}$ & $10^{9.43}$ & $10^{9.5}$ & $10^{9.62}$ & $10^{10}$ & $10^{10}$ \\
\hline 5. & 24 & Nil & Nil & Nil & Nil & $2^{7}$ & $10^{9.16}$ & $10^{9.33}$ & $10^{10}$ & $10^{9.24}$ & $10^{10}$ \\
\hline 6. & 30 & Nil & Nil & Nil & Nil & $2^{7}$ & $10^{9.24}$ & $10^{8.87}$ & $10^{9.39}$ & $10^{9.25}$ & $10^{9.62}$ \\
\hline
\end{tabular}

Table. 4 the HA titre and $\mathrm{EID}_{50}$ of the virus in the fourth thermal cycle exposed at $43^{0} \mathrm{C}$ for 30 days

\begin{tabular}{|c|c|c|c|}
\hline Sl. no. & Period of thermal exposure (in days) & HA titre & EID $_{50}$ \\
\hline 1. & 0 (before thermal exposure) & $2^{10}$ & $10^{9.25}$ \\
\hline 2. & 6 & $2^{6}$ & $10^{9.24}$ \\
\hline 3. & 12 & $2^{4}$ & $10^{8.25}$ \\
\hline 4. & 18 & - & $10^{7.43}$ \\
\hline 5. & 24 & - & $10^{7.69}$ \\
\hline 6. & 30 & - & $10^{7.5}$ \\
\hline
\end{tabular}

The selected virus was serially passaged in 911 days old embryonated SPF fowl eggs and observed no embryopathy on $45^{\text {th }}$ passage. For confirmation of attenuation, the passaged virus was inoculated @ $10^{6.5}$ EID $_{50}$ oronasally to 10 , five days old SPF chicks and observed no abnormality/mortality for 21 days post inoculation. The $44^{\text {th }}$ passaged virus was inoculated into five 9-11 days old embryonated SPF fowl eggs and allantoic fluids were harvested after 5 days of post inoculation. After estimation of HA titre separately the allantoic fluid was pooled together considered as master seed virus and the HA titre and $\mathrm{EID}_{50}$ was estimated. The master seed virus was given three serial passages in SPF fowl eggs. Allantoic fluid was harvested after 5 days of incubation and HA titre was estimated. Finally, the allantoic fluids of 3 passages were pooled together considered as working seed virus and the HA titre and $\mathrm{EID}_{50}$ was estimated. The working seed virus was serially inoculated for three passages in SPF fowl eggs. After 5 days of incubation, allantoic fluids were harvested from every passage of each inoculated egg and HA titre was determined as per the OIE (2009). Finally, the allantoic fluids of the three passages were pooled together considered as vaccine and HA titre was determined as per the OIE (2009). The vaccine dose was calculated by determining the $\mathrm{EID}_{50}$ as per the method of FAO (2002) and Reed and Muench (1938). For confirmation of vaccine virus as APMV-1, HI test was performed using known positive antisera of APMV-1 (Table 3 and 4).

The selected lentogenic strain ND virus (local isolate) could withstand the thermal exposure of $40^{\circ} \mathrm{C}$ for 30 days and $43^{\circ} \mathrm{C}$ for 12 days without losing its viability and infectivity in 
laboratory condition and used as vaccine after attenuation.

\section{Acknowledgement}

DST Inspire Fellowship

\section{References}

Bensink, Z. and Spradbrow, P. B. 1999. Newcastle disease virus strain $I_{2}$, a prospective thermo stable vaccine for use in developing countries. Veterinary Microbiology, 68: 131-139.

Bhagat, S. 2014. Studies on thermostability of a lentogenic strain of Newcastle disease virus (local isolate) and its seroconversion in broiler chicks. M.V.Sc. dissertation works submitted to West Bengal University of Animal and Fishery Sciences.

Biswas, U. 2006. Isolation, characterization of Ranikhet Disease (RD) virus along with sero-epidemiological study in West Bengal. $\mathrm{Ph}$.D. dissertation works submitted to West Bengal University of Animal and Fishery Sciences.

Chakraborty, D., Guha, C., Biswas, U., Chatterjee, A., Jana, P. S., Biswas, S., Sharma, L., Pradhan, N., Bhagat, S. and Naha, B.C. 2014. Studies on thermo stability of Newcastle disease virus (local isolate) for preparation of vaccine. Journal of Medical Science and Clinical Research, 2 (1): 327331.

Commission of the European Communities, 1993. Commission decision of $8^{\text {th }}$ Feb. 1993 laying down the criteria for vaccines to be used against Newcastle disease in the context of routine vaccination programmes. Off. J. European Communities. L59, 35.

FAO 2002. Basic laboratory manual of the smallscale production and testing of $1_{2}$ Newcastle disease vaccine.
Ideris A., Ibrahim A.L., Spradbrow, P.B., and Hung Seng C. 1987. Development of food pellet Newcastle disease vaccine. In: Copland J.W. (ed.): Newcastle disease in poultry: a new food pellet vaccine. Canberra, ACIAR, pp. 20-23.

Nssien, M. A. S. and Adene. D. F. 2002. Thermo stability of reconstituted Newcastle disease virus strains at $36^{\circ} \mathrm{C}$ temperature. African Journal of Biomedical Research, 5: 87 - 89.

OIE 2000. Newcastle Disease, Manual of standard for diagnostic tests and vaccines.5th edition Office International des Epizootics, (OIE), Paris, pp.104-124.

OIE Manual 2004. Newcastle disease. Chapter 2.1.15. In: Office of International des Epizooties.

OIE Manual 2009. Newcastle disease. Chapter 2.1.15. In: Office of International des Epizooties.

OIE Manual 2012. Newcastle disease. Chapter 2.3.14. In: Office of International des Epizooties.

Reed, L.J. and Muench, L.H. 1938. A simple method of estimating fifty percentend points. Amer. J. Hygeine. 27: 493-497.

Spradbrow, P. 1992. Newcastle disease in village chicken: control with thermo stable oral vaccines. Proceedings of an international workshop held in Kuala Lumpur, Malaysia. ACIAR, 39:189.

Spradbrow, P. B., MacKenzie, B. and Grimes, S.E. 1995. Recent isolates of Newcastle disease virus in Australia. Veterinary Microbiology, 46: 2 I-28.

Usman, M. 2002. Effects of vaccination of chickens against Newcastle disease with thermo stable $\mathrm{V}_{4}$ and Lasota vaccines using different grains and their brans as vehicles. M.Sc. Thesis, Department of Veterinary Surgery and Medicine, Ahmadu Bello Unviersity, Zaria, Nigeria.

\section{How to cite this article:}

Sharma, L., U. Biswas, C. Guha, A. Chatterjee, P.S. Jana and Pandey, R. 2018. Studies on Thermostability of Newcastle Disease Viruses (Local Isolates) for Preparation of Vaccine. Int.J.Curr.Microbiol.App.Sci. 7(01): 506-510. doi: https://doi.org/10.20546/ijcmas.2018.701.060 